\title{
Methods of asepsis for in vitro establishment and germination of Eucalyptus grandis
}

\author{
Berenice Kussumoto Alcântara ${ }^{1^{*}}$, Gilvano Ebling Brondani ${ }^{2 *}$, Antônio Natal Gonçalves ${ }^{2}$, \\ Marcílio de Almeida ${ }^{3}$ and Ricardo Antunes Azevedo ${ }^{1}$
}

${ }^{1}$ Departamento de Genética; PPG Internacional Biologia Celular e Molecular Vegetal, Escola Superior de Agricultura "Luiz de Queiroz"/Universidade de São Paulo - ESALQ/USP; 13.418-900; Piracicaba - SP - Brasil. ${ }^{2}$ Departamento de Ciências Florestais, PPG em Recursos Florestais; Escola Superior de Agricultura "Luiz de Queiroz"/Universidade de São Paulo - ESALQ/USP; 13.418-900; Piracicaba - SP - Brasil. ${ }^{3}$ Departamento de Ciências Biológicas; PPG em Fisiologia e Bioquímica de Plantas, Escola Superior de Agricultura "Luiz de Queiroz"/Universidade de São Paulo - ESALQ/USP; 13.418-900; Piracicaba - SP - Brasil. *Bolsista FAPESP.

\begin{abstract}
Technical and scientific studies have been conducted for the cultivation of Eucalyptus, with special attention to large-scale clonal propagation. However, in some studies are necessary to obtain aseptic material from seeds, and as far as we are aware efficient protocols of asepsis for this purpose are still not available. Therefore, this study aimed to define a protocol for sterilization of seeds of Eucalyptus grandis for in vitro establishment and germination. Four methods of sterilization were tested using different application sequences of the disinfectants, as benomyl fungicide, hydroalcoholic solution $(70 \% \mathrm{v} / \mathrm{v})$ and sodium hypochlorite $(\mathrm{NaOCl})$. The experiment was conducted in completely randomized design with five repetitions. The percentage of establishment and contamination were evaluated at the end of the experiment. Washing with sterile water and $70 \%$ alcohol for $30 \mathrm{~s}$, $2.5 \%$ sodium hypochlorite for $20 \mathrm{~min}$, $1 \%$ benomyl for 20 min and three washes with sterile water was the best method found, accounting to $87.5 \%$ of establishment.
\end{abstract}

Key words: Disinfestation of seeds, water-alcohol solution, sodium hypochlorite, in vitro culture

\section{INTRODUCTION}

Currently, there are several protocols for aseptic micropropagation establishment of different types of explants of Eucalyptus (Alves et al., 2004; Bandeira et al., 2006; Brondani et al., 2009, Aggarwal et al., 2010; Huang et al., 2010). However, there are papers that do not elucidate clearly the process of disinfection of seeds for germination in vitro to obtain aseptic seedlings (Souza et al., 1999; Basso et al., 2007). The process for the establishment of Eucalyptus in vitro using seeds has been laborious mainly due to the size of them and the method of processing that generate a mixture with high amount of inert materials, which may be responsible for the simultaneous inoculation of bacteria and fungi, and in turn delay in the establishment of seed culture medium in vitro.

In vitro tissue culture is important to offer high rates of multiplication from segments of tissue, however it is also an efficient tool for obtaining large numbers of individuals free of contaminating sources (Dutra et al., 2009; Hossain et al., 2010; Hung and Trueman, 2010; Silva et al., 2010; Silva et al., 2011). Since the seeds of Eucalyptus are subjected to intense exchange of germplasm, methods of seed cultivation in vitro offer alternatives to mitigate these problems, limiting the spread of pests and diseases such as rust. Additionally, in vitro germination methods can be applied to the improvement of biotechnology techniques, such as the proliferation of hybrids, selected genotypes and the development of new cultivars from bioengineering techniques.

The benomyl fungicide (methyl 1-butyl-carbomyl 2-benzimidazole carbamate) has been recommended for the control of various fungi such as Pestalotiopsis sp., Cladosporium cladosporioides, Phoma sp., Alternaria sp., Botryodiplodia sp., Drechslera sp., Curvularia sp.,

Author for correspondence: berenice@esalq.usp.br, gebrondani@yahoo.com.br 
Aspergillus sp., Epicoccum sp. and Penicillium sp. (Lisbon-Padulla et al., 2009) and it is considered a systemic fungicide that is absorbed and translocated by plant cells and organs, protecting the culture medium as well the plant material (Yang, 1976). When compared with other active ingredients of fungicides, benomyl is the most effective in the treatment of radish seeds (Raphanus sativus) and carrot (Daucus carota), presenting the lower percentage of infestation in vitro (Boughalleb et al., 2006). However, as far as we are aware there are no reports that relate the use of this fungicide with the in vitro establishment of seeds of Eucalyptus. There are only reports that use benomyl for treatment of fungal attack on leaves (Carnegie and Ades, 2003) and stems of Eucalyptus (Carrero et al., 2003). Additionally, bacterial contamination can also affect the in vitro cultivation and limit the growth of the explants (Brondani et al., 2010). Therefore, it is necessary to develop efficient protocols for success during the in vitro introduction, considering the type and source of explant.

Additional treatments with sodium hypochlorite (2.5\% of active chlorine) and water-alcohol solutions are used for the process of aseptic explants of Eucalyptus (Brondani et al., 2009; Dutra et al., 2009), however the concentrations, the sequence of treatments and the time of exposure to aseptic agents should be established to eliminate fungi and bacteria efficiently and at the same time, preventing the failure of the explants. For tissue culture, in which specific steps are required to obtain disinfected materials under in vitro conditions, the sources of contamination substantially limit the establishment of seeds. However, inoculums can be adhered to their surfaces and also can be found internally, either in the tegument or embryo (Netto and Faiad, 1995). For this reason, it is important to study the use of a systemic fungicide, as benomyl, for the process of disinfection of seeds, as well as the action of sodium hypochlorite and water-alcohol solutions. The sequence and timing of exposure to each aseptic agent can influence different responses to the in vitro establishment.

Therefore, the present study intended to determine an efficient protocol for sterilization of seeds of Eucalyptus grandis aiming the in vitro establishment and germination.

\section{MATERIAL AND METHODS Source material}

Seeds of Eucalyptus grandis W. Hill. Ex Maiden were collected from a Seed Orchard (SO) located at the Anhembi-SP, Brazil. The SO belongs to the Institute of Research and Forestry Studies Instituto de Pesquisa e Estudos Florestais (IPEF). The cultivar was identified as LCFA001 A11A21 cultivar, which corresponded to the lot AN0166N01 collection of the 2007 harvest.

\section{Treatments}

Treatments were four seed sterilization procedures for the establishment in vitro, and the sequence of steps are listed in Table 1.

Table 1. Treatments of asepsis for in vitro establishment and germination of Eucalyptus grandis seeds.

\begin{tabular}{ccccccccccc}
\hline \multirow{2}{*}{ Treatments } & $1^{\text {st }}$ & $2^{\text {nd }}$ & $3^{\text {rd }}$ & $4^{\text {th }}$ & $5^{\text {th }}$ & $6^{\text {th }}$ & $7^{\text {th }}$ & $8^{\text {th }}$ & $9^{\text {th }}$ & $10^{\text {th }}$ \\
\hline Asepsis 1 & A & B & C & D & C & E & C & C & C & - \\
Asepsis 2 & A & C & D & C & E & C & B & C & C & C \\
Asepsis 3 & A & C & D & C & B & C & E & C & C & C \\
Asepsis 4 & A & C & B & C & E & C & C & C & - & - \\
\hline
\end{tabular}

*A = water for 15 minutes; $\mathrm{B}=$ immersion in benomyl fungicide at $1 \%$ for 20 min with deionized and autoclaved water; $\mathrm{C}=$ washing with deionized and autoclaved water; $\mathrm{D}=$ immersion in water-alcohol solution at $70 \%$ for 30 seconds; $\mathrm{E}=$ immersion in sodium hypochlorite $(\mathrm{NaOCl})$ solution at $2.5 \%$ of active chlorine for 20 minutes.

\section{Preparation of culture medium}

The MS medium (Murashige and Skoog, 1962) was supplemented with 30 g.. $\mathrm{L}^{-1}$ sucrose and 9 g.L $\mathrm{L}^{-}$ ${ }^{1}$ agar. The $\mathrm{pH}$ was adjusted to 5.8 with $\mathrm{KOH}(1 \mathrm{M})$ and/or $\mathrm{HCl}(1 \mathrm{M})$ before adding the agar. After this step, the culture medium was autoclaved for 20 minutes at $121{ }^{\circ} \mathrm{C}\left(1 \mathrm{kgf} . \mathrm{cm}^{-2}\right)$. The culture medium was not supplemented with growth regulators. 


\section{Experimental unit and growing conditions}

The experimental unit was a glass $(7 \times 6.5 \mathrm{~cm})$ containing $40 \mathrm{~mL}$ of culture medium and about 0.40 grams of seeds, which were arranged randomly on the surface of the culture medium.

The experimental units were placed in a growth chamber at temperature of $25{ }^{\circ} \mathrm{C}\left( \pm 2{ }^{\circ} \mathrm{C}\right)$, photoperiod of 12 hours and light intensity of 40 $\mu \mathrm{mol} . \mathrm{m}^{-2} \cdot \mathrm{s}^{-1}$.

\section{Variables analyzed}

After 18 days in culture, we analyzed the percentage of fungal and bacterial contamination, oxidation and in vitro establishment using the criteria of presence and absence. It was considered established, the experimental units free from contamination.

\section{Experimental design}

The experiment was conducted in a randomized design, testing four treatments to establish seeds in vitro (Table 1) and five replications.

\section{Data analysis}

The data were subjected to Hartley test $(P<0.05)$ to verify the homogeneity of variance between treatments. We also analyzed the variance (ANOVA, $P<0.01$ and $P<0.05$ ) and, according to significance, means were compared by Tukey test $(P<0.05)$. We used the SOC software (EMBRAPA, 1990) to achieve the statistical procedures.

\section{RESULTS AND DISCUSSION}

According to the variance analysis, the effect of four different ordinations of asepsis was highly significant for the establishment of seeds of Eucalyptus grandis (Table 2). Note that the bacterial and fungal contamination influenced the establishment of the seeds significantly (Figure 1), and the asepsis 2 (wash with water followed by $70 \%$ ethanol for $30 \mathrm{~s}, 2.5 \%$ sodium hypochlorite for $20 \mathrm{~min}$ and benomyl fungicide $1 \%$ for $20 \mathrm{~min}$ as a final disinfectant) was the best method observed $(87.5 \%$ of establishment), differing significantly from the others. The same method also resulted in an increase in oxidation, but it did not affect the establishment and germination.

Table 2. Variance analysis for the establishment (EST), oxidation (OXI), bacterial contamination (BAC) and fungal contamination (FUN) of Eucalyptus grandis seeds inoculated on MS medium, 18 days after the introduction.

\begin{tabular}{llllll}
\hline \multirow{2}{c}{$\begin{array}{c}\text { Variation } \\
\text { Causes }\end{array}$} & \multirow{2}{*}{ GL } & \multicolumn{4}{c}{ Mean Squares } \\
\cline { 3 - 6 } & & EST & OXI & BAC & FUN \\
\hline Treatment & 3 & $1.0476^{* * *}$ & $0.5119^{* * *}$ & $0.6071^{*}$ & $1.0000^{* *}$ \\
Residue & 24 & 0.1071 & 0.1071 & 0.1428 & 0.1667 \\
Mean $(\%)$ & - & 28.6 & 17.9 & 25.0 & 50.0 \\
CV $(\%)$ & - & 22.45 & 25.58 & 14.66 & 21.22 \\
\hline
\end{tabular}

\footnotetext{
$*$ and $* *$ significant value at $5 \%$ and $1 \%$ level of probability, respectively.
} 


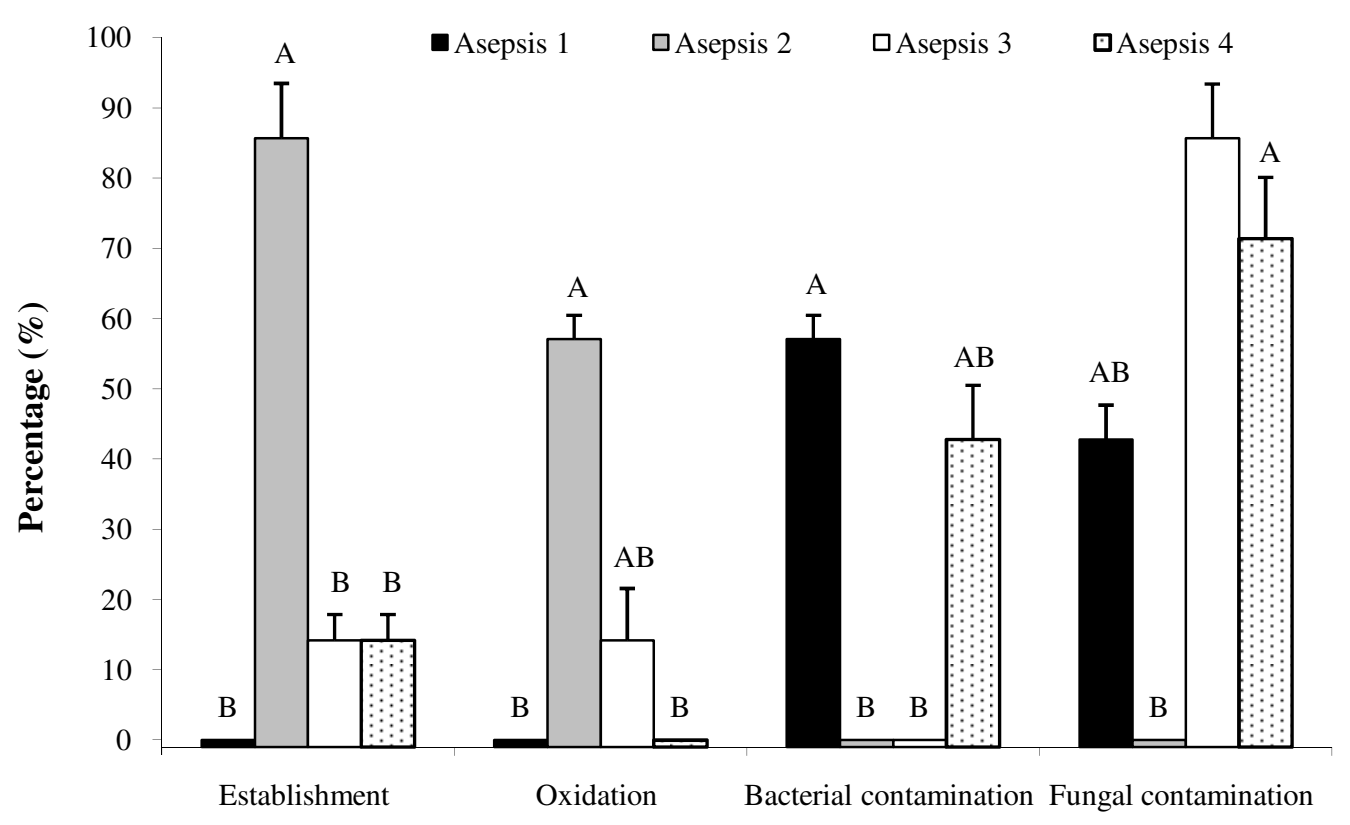

Figure 1 - Mean values of percentage of establishment (EST), oxidation (OXI), bacterial contamination (BAC) and fungal contamination (FUN) of Eucalyptus grandis seeds in relation to treatments. Averages with the same letter within each trait, did not differ significantly by Tukey test at $5 \%$ probability of error. The steps of the methods of asepsis 1, 2, 3 and 4 are shown in Table 1.

The method of sterilization with the lowest establishment $(0 \%)$ was the first method (washing with water followed by benomyl $1 \%$ for $20 \mathrm{~min}$, $70 \%$ alcohol for $30 \mathrm{~s}$ and $2.5 \%$ sodium hypochlorite as a final disinfectant for $20 \mathrm{~min}$ ), which exhibited the highest bacterial contamination $(57.1 \%)$ and also high fungal contamination $(42.8 \%)$, whose results suggest that such a method should not be used and we do not recommend. Methods 3 and 4 presented low percentage of establishment (14.2\%) being lower than the second method (Figures 2 and 3). It was also observed that the third method tested (washing with water followed by $70 \%$ ethanol for $30 \mathrm{~s}$, benomyl $1 \%$ for $20 \mathrm{~min}$ and $2.5 \%$ sodium hypochlorite as a final disinfectant for 20 minutes), resulted in the highest fungal contamination $(85.7 \%)$, but on the other hand it was the one with the lowest bacterial contamination $(0 \%)$. Finally, method 4 (washing with water followed by benomyl $1 \%$ for $20 \mathrm{~min}$ and $2.5 \%$ sodium hypochlorite as a final disinfectant for 20 minutes) also failed to completely eliminate contamination, resulting in high bacterial contamination (42.8\%) and high fungal contamination (71.4\%).

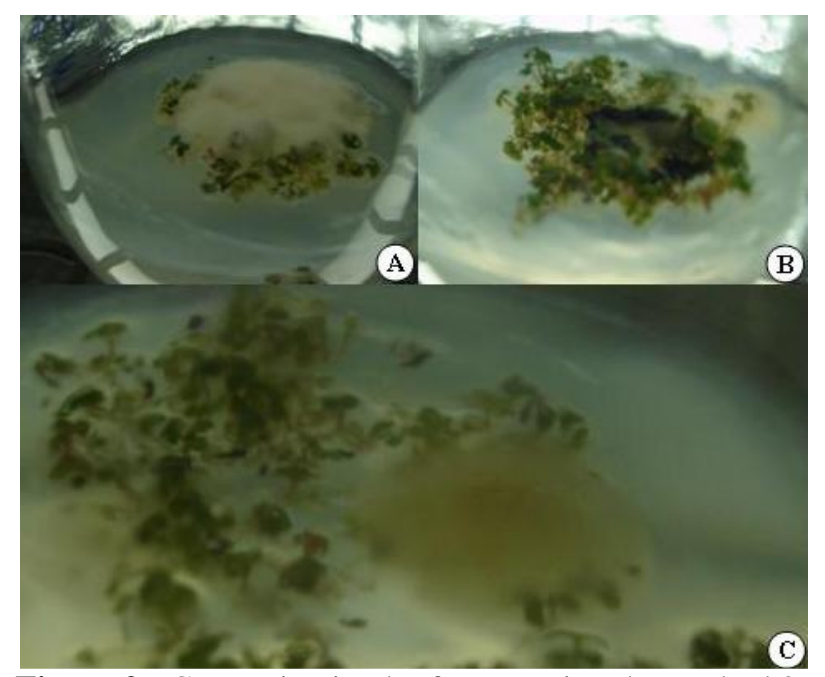

Figure 2 - Contamination by fungus using the method 3 of asepsis (A) and method 4 (B); bacterial contamination found in the method 1 of asepsis (C).

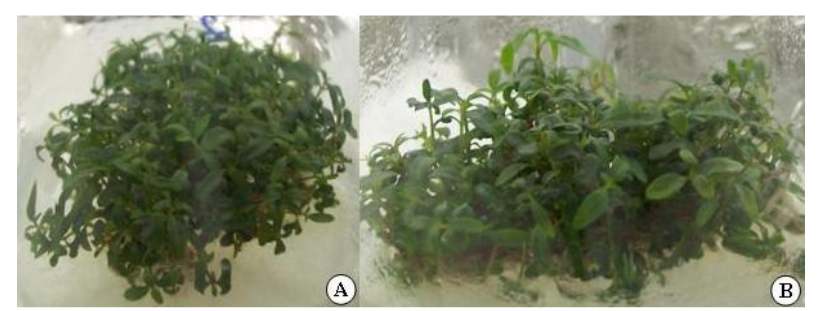

Figure 3 - Establishment of Eucalyptus grandis seedlings after 26 days using the method 2 of asepsis which was the best method observed (A) and (B). 


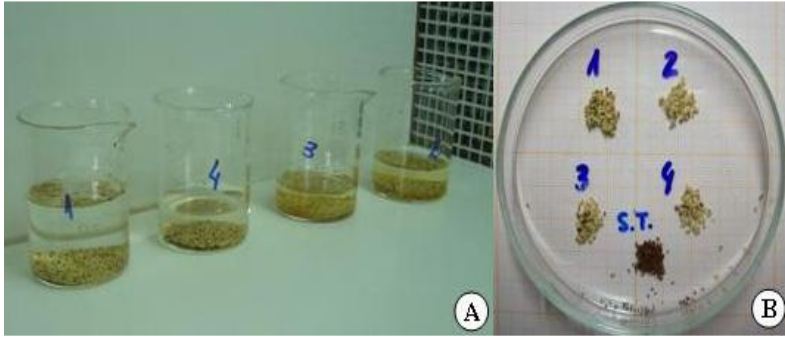

Figure 4 - Treatments of asepsis after application of sodium hypochlorite (A); comparison of Eucalyptus grandis treated (1, 2, 3 and 4) between the seeds of Eucalyptus grandis without treatment (S.T.), showing the discoloration caused by the removal of seed tegument after application of hypochlorite (B).

On the other hand, we also observed that the method 2 of sterilization had the highest percentage of oxidation (darkening of the medium), although it did not affect the establishment of seeds of Eucalyptus grandis. Such a level of oxidation can be explained because of the action of benomyl that was potentiated by this method. No other reports were found in respect to cellular oxidation caused by benomyl, however Ray (1984) reported that the fungicide is responsible for the oxidation of sulfur to sulfate leading to the acidification of the soil by the change in $\mathrm{pH}$. The oxidation of sulfur to sulfate allows the sulfur to be more available to plants since they cannot uptake the elemental form (Bonato et al., 1998). Consequently, the oxidation does not affect the establishment, since sulfur is an essential element, component of an essential amino acid (methionine), which is also part of a nonessential amino acid, the cysteine (Azevedo et al., 1997; Azevedo and Arruda, 2010).

\section{CONCLUSIONS}

We do not recommend the use of benomyl in stages prior to the use of sodium hypochlorite for disinfection of Eucalyptus grandis seeds, because this method of sterilization was not effective.

The best method for in vitro establishment and germination of seeds of Eucalyptus grandis was washing with water followed by $70 \%$ ethanol for $30 \mathrm{~s}, 2.5 \%$ sodium hypochlorite for $20 \mathrm{~min}, 1 \%$ benomyl for $20 \mathrm{~min}$ and three washes with deionized and autoclaved water.

The oxidation observed in the treatment which uses the benomyl after the hypochlorite does not affect the establishment since the oxidation may be occurring in elemental sulfur resulting sulfate, which is actually benefic to the plants.

\section{ACKNOWLEDGEMENTS}

We are grateful to José Roberto Romanini for assisting in the assembly of the experiment and to FAPESP for financial support.

\section{RESUMO}

Muitos estudos técnicos e científicos têm sido realizados para a cultura do eucalipto, principalmente no que tange a área da propagação clonal em larga escala. Entretanto, em alguns estudos são necessários a obtenção de materiais assépticos via sementes, e para tal finalidade não se encontram protocolos eficientes de assepsia. Visto essa problemática, o presente estudo teve como objetivo a definição de um protocolo para assepsia de sementes de Eucalyptus grandis para o estabelecimento e germinação in vitro. Foram testados quatro métodos de assepsia utilizando fungicida a base de benomyl, solução hidroalcoólica $(70 \%$ v/v $)$ e hipoclorito de sódio $(\mathrm{NaOCl})$, alternando a ordem de aplicação. $\mathrm{O}$ experimento foi conduzido no delineamento inteiramente casualizado com cinco repetições. A porcentagem de estabelecimento e contaminação foram avaliadas ao final do experimento. O melhor método encontrado foi aquele em que se utilizou a sequência de lavagem com água esterilizada seguida de álcool $70 \%$ por $30 \mathrm{~s}$, hipoclorito de sódio à $2,5 \%$ por 20 min, fungicida a base de benomyl $1 \%$ por 20 min e três lavagens com água esterilizada, correspondendo a $87,5 \%$ de estabelecimento.

Palavras-chave: Desinfestação de sementes, solução hidroalcoólica, hipoclorito de sódio, cultivo in vitro

\section{REFERENCES}

Aggarwal, D.; Kumar, A.; Reddy, M. S. (2010), Shoot organogenesis in elite clones of Eucalyptus tereticornis. Plant Cell Tissue and Organ Culture, Netherlands, 102, 45-52.

Alves, E. C. S. C.; Xavier, A.; Otoni, W. C. (2004), Organogênese in vitro a partir de explante caulinar na regeneração de clones de Eucalyptus grandis W. Hill ex Maiden x E. urophylla S. T. Blake. Revista Árvore, 28, 643-653.

Azevedo, R. A. and Arruda, P. (2010), High-lysine maize: the key discoveries that have made it possible. Amino Acids, 39, 979-989.

Azevedo, R. A.; Arruda, P.; Turner, W. L.; Lea, P. J. (1997), The biosynthesis and metabolism of the aspartate derived amino acids in higher plants. Phytochemistry, 46, 395-419. 
Bandeira, F. S.; Xavier, A.; Otoni, W. C.; Dias, J. M. M. (2006), Enxertia in vitro na propagação de clones de Eucalyptus urophylla e E. grandis. Pesquisa Agropecuária Brasileira, 41, 223-232.

Basso, L. H. M.; Lima, G. P. P.; Gonçalves, A. N.; Vilhena, S.M.C.; Padilha, C.C.F. (2007), Effect of aluminum on the free polyamines content and acid phosphatase activity during the growth of Eucalyptus grandis $\mathrm{x}$ E. urophylla shoots cultivated in vitro. Scientia Forestalis, 75, 9-18.

Bonato, C. M.; Rubin Filho, C. J.; Melges, E.; Santos, V. D. (1998), Nutrição Mineral de Plantas. Maringá: Universidade Estadual de Maringá. 60p.

Boughalleb, N.; Tarchoun, N.; Dallagi, W. (2006), Effect of fungicides on in vitro infestation level of radish, carrot and pepper seeds. Plant Pathology Journal, 5, 388-392.

Brondani G. E.; Dutra, L. F.; Grossi, F. G.; Wendling, I.; Azevedo, J. H. (2009), Estabelecimento, multiplicação e alongamento in vitro de Eucalyptus benthamii Maiden \& Cambage x Eucalyptus dunnii Maiden. Revista Árvore, 33, 11-19.

Brondani, G. E.; Hansel, F. A.; Dutra, L. F.; Wendling, I. (2010), Desinfestação e meio de cultura para o estabelecimento in vitro de segmentos nodais de Liquidambar styraciflua. Floresta, 40, 541-554.

Carnegie, A. J. and Ades, P. K. (2003), Mycosphaerella leaf disease reduces growth of plantation-grown Eucalyptus globulus. Australian Forestry, 66, 113-119.

Carrero, C.; Cedeño, L.; Quintero, K.; Pino, H.; Rodríguez, L. (2003), Identification and in vitro sensitivity to fungicides of the causal agent of stem rot on Eucalyptus cinerea seedlings in Mérida, Venezuela. Interciencia, 28, 656-659.

Dutra, L. F.; Wendling, I.; Brondani, G. E. (2009), A micropropagação do eucalipto. Pesquisa Florestal Brasileira, 58, 49-59.

Embrapa. Empresa Brasileira de Pesquisa Agropecuária. (2009), Programa SOC - Software
Científico, Versão 2.1, Embrapa Informática Agropecuária, Campinas.

Hossain, H. M. M. T.; Kim, Y. H.; Lee, Y. S. (2010), The apical bud as a novel explant for highfrequency in vitro plantlet regeneration of Perilla frutescens L. Britton. Plant Biotechnology Reports, 4, 229-235.

Huang, Z. C.; Zeng, F. H.; Lu, X. Y. (2010), Efficient regeneration of Eucalyptus urophylla from seedling-derived hypocotyls. Biologia Plantarum, 54, 131-134.

Hung, C. D. and Trueman, S. J. (2010), Nutrient responses differ between node and organogenic cultures of Corymbia torelliana x C. citriodora (Myrtaceae). Australian Journal of Botany, 58, 410-419.

Lisboa-Padulla, T.; Moraes, M. H. D.; Menten, J. O. M.; Barbedo, C. (2009), Tratamento de sementes de pau-brasil com fungicidas: efeito na incidência de fungos, germinação e transmissão de fungos pelas sementes. Summa Phytopathologica, 35, $148-150$.

Murashige, T. and Skoog, F. A. (1962), Revised medium for rapid growth and bioassays with tobacco tissue cultures. Physiologia Plantarum, 3, 473-497.

Netto, D. A. M. and Faiad, M. G. R. (1995), Viabilidade e sanidade de sementes de espécies florestais. Revista Brasileira de Sementes, 17, 7580, 1995.

Ray, R. C. (1984), Effect of some pesticide combinations on sulfur oxidation in the simulated oxidized layer of a flooded soil. Environmental Pollution, 34, 15-22.

Silva, A. L. L.; Oliveira, Y.; Costa, J. L.; Masetto, E.; Mudry, C. S.; Erasmo, E. A. L.; Scheidt, G. N. (2010), Shoot tip and cotyledon explants of Eucalyptus saligna $\mathrm{Sm}$. cultivated on different kanamycin levels. Journal of Biotechnology and Biodiversity, 1, 1-5.

Silva, A. L. L.; Oliveira, Y.; Costa, J. L.; Mudry, C. S.; Procopiuk, M.; Scheidt, G.N.; Brondani, G. E. (2011), Preliminary results for genetic 
transformation of shoot tip of Eucalyptus saligna Sm. via Agrobacterium tumefaciens. Journal of Biotechnology and Biodiversity, 2, 1-6.

Souza, G. M.; Gonçalves, A. N.; Machado Neto, N. B. (1999), Crescimento in vitro de progênies de Eucalyptus camaldulensis Dehn. sob condições de deficiência hídrica. Scientia Agricola, 56, 557-562.
Yang, H. J. (1976), Effect of benomyl on Asparagus officinalis L. shoot and root development in culture media. Horticultural Science, 11, 473-474. 